\title{
KEBIJAKAN PENDIDIKAN DI AMERIKA SERIKAT
}

Taat Wulandari ${ }^{1}$

\begin{abstract}
Regarding education is a means of countries to develop, there are some policies and strategies to fulfill the above mission. Such as to provide good infrastructures and structures to develop curriculum, to develop the quality of teachers, to increase education budget and to adopt the good aspect of others education system.

This article is to elaborate education system in United States of America. Despite there are some countries which have good education system, USA has relatively good education system. It is not surprisingly that there are some qualified universities, so that some students choose these universities for studying. Up to now the numbers of Indonesian graduate from USA is still in the first range.
\end{abstract}

Keywords: Education, policy.

\section{A. Pendahuluan}

Sudah banyak contohnya bahwa pendidikan mampu membawa perubahan dalam berbagai aspek. Entah itu dalam aspek ekonomi, sosial, politik, budaya, dan tentu saja dalam penguasaan wawasan keilmuan. Jepang adalah salah satu negara yang sukses menjadi bangsa yang besar dalam hal pendidikan dan pengetahuan dengan mengirim generasi mudanya sekolah di luar negeri. Dari negeri matahari terbit ini telah ditunjukkan bagaimana meluasnya pendidikan secara cepat mampu membantu terjadinya modernisasi Jepang. Negara ini dalam kenyataannya mempunyai peraturan wajib belajar di seluruh negeri dan sudah menjadi nomor dua sesudah Amerika dalam hal jumlah siswa yang menerima pendidikan tinggi. ${ }^{2}$

Bagaimana dengan Amerika Serikat? Pendidikan di Amerika Serikat sudah dirintis pada masa Amerika Serikat belum terbentuk. Negara ini malah belum memproklamasikan kemerdekaannya ketika College-college sebagai dasar pendidikan Amerika didirikan oleh pemerintah kolonial. Pada masa-masa awal, rakyat di seluruh koloni sudah sadar bahwa yang paling penting untuk masa depan adalah dasar-dasar pendidikan dan budaya Amerika. Hal ini terus

\footnotetext{
${ }^{1}$ Staff pengajar pada Jurusan Pendidikan Sejarah, FISE, UNY.

${ }^{2}$ Tadashi Fukutake. (1988). Masyarakat Jepang Dewasa Ini. Jakarta: PT. Gramedia Pustaka,
} hlm. 203. 
berlanjut pada masa kolonial, diteruskan dan semakin disempurnakan pada masa-masa berikutnya sampai sekarang.

Amerika Serikat yang sudah berumur ratusan tahun sejak kemerdekaannya tentunya memiliki banyak pengalaman dalam mencari format pendidikan yang cocok. Pada tahun 1636 di Cambridge, Massachussetts telah didirikan Harvard College. Akhir abad XVII didirikan College of William dan College of Mary di Virginia. Beberapa tahun kemudian didirikan College School of Connecicut, yang kemudian menjadi Yale College. Dan pada awal perkembangannya banyak juga sekolah-sekolah yang diselenggarakan oleh golongan keagamaan. Seperti diketahui sekolah-sekolah tersebut di atas pada kenyataannya tetap eksis sampai sekarang.

Bagaimana dan seperti apa kebijakan pendidikan di AS tentunya sangat bisa menjadi wacana bagi pemerhati masalah-masalah pendidikan. Sebuah negara yang maju tentunya mempunyai sistem pendidikan yang baik pula.

\section{B. Politik Pendidikan AS}

Kekuasaan adalah segalanya. Kekuasaan pula dapat memberikan corak dari setiap kebijakan yang akan diambil oleh pengambil kebijakan (negara). Penguasa dengan kekuasaan dan kekuatan yang dimiliki dapat menentukan mau seperti apa aspek-aspek kehidupan yang harus dijalankan menurut kepentigannya. Tidak hanya aspek kenegaraan, ekonomi, social, budaya, bahkan pendidikan pun dapat dijadikan alat penguasanya.

Pada umumnya kebijakan pendidikan yang diambil di suatu Negara cenderung dijadikan alat intervensi negara kepada warga negaranya. Bentuk intervensi itu dapat berupa justifikasi (diakui/tidaknya) ilmu pengetahuan tertentu, pengaturan kelembagaan sekolah, lama pendidikan dan gelar, serta kualifikasi pendidikan yang dikaitkan dengan posisi pekerjaan (jabatan). Pada tataran pendidikan tertentu biasanya akan lebih mudah untuk dilaksanakan intervensi tersebut. Di antara jenjang pendidikan sekolah (mulai dari tingkat dasar hingga Perguruan Tinggi) yang ada, umumnya Negara lebih memilih mengkonsentrasikan kekuasaannya untuk mengintervensi pendidikan sekolah yang diperuntukkan bagi anak-anak, remaja dan kaum muda. Hampir tidak ada negara yang menaruh perhatian cukup besar pada pendidikan untuk orangorang dewasa.

Pertanyaannya adalah; mengapa negara lebih memilih memusatkan perhatiannya kepada pendidikan anak-anak (muda) dibandingkan dengan 
pendidikan orang dewasa?. Sebenarnya jawabannya sepele saja, karena anakanak muda adalah generasi penerus bangsa. Pada tingkat anak-anak (muda) sangat mudah untuk dipengaruhi pola berpikirnya. Dengan demikian masamasa itu harus dijadikan timing yang tepat untuk membentuknya. Sebagian negara yang lain memiliki alasan bahwa sekolah cukup menarik untuk dikuasai, dimana di dalamnya terdapat generasi yang sangat mudah untuk dipengaruhi. Ada juga sebagian negara beralasan karena hak suara untuk pemilihan politik di masa yang akan datang perlu proses sosialisasi, dan itu cocok dilakukan untuk anak-anak melalui sekolah-sekolahnya.

Pendidikan bagi sebagian masyarakat sudah dianggap sebagai kebutuhan dasar dan bukan lagi menjadi kebutuhan sekunder. Karena itu para orang tua berbondong-bondong memasukkan anaknya di berbagai lembaga pendidikan, terutama lembaga pendidikan formal yang diselenggarakan atau diakreditasi oleh negara. Campur tangan dan intervensi negara pada pendidikan sekolah formal tampaknya sering diabaikan oleh para orang tua. Oleh sebab itu perlu adanya mekanisme pengawasan yang dilakukan oleh orang-orang dewasa (masyarakat) setempat terhadap penyelengaraan pendidikan sekolah-sekolah formal agar intervensi (kebijakan) negara dalam sektor pendidikan bermakna positif bagi generasi berikutnya yang lebih handal, sekaligus untuk mengurangi terjadinya peluang penyimpangan yang mungkin dilakukan negara dalam kegiatan intervensinya itu.

Di negara-negara demokrasi, kesadaran untuk mengawasi dan membatasi intervensi pemerintah pada sektor pendidikan itu ditandai dengan dipilihnya asas desentralisasi dalam pengambilan kebijakan (pengaturan) sektor pendidikan. Amerika Serikat adalah salah satu Negara pelopor demokrasi. Sudah sejak lama kebijakan pendidikan di Amerika Serikat menjadi tanggung jawab Pemerintah Negara Bagian (State) dan Pemerintah Daerah (Distrik). Sebelumnya, Pemerintah Pusat memang mengintervensi kebijakan pendidikan, sebagaimana yang terjadi sejak tahun 1872, dimana Pemerintah Pusat AS mengintervensi kebijakan pendidikan dengan cara memberikan tanah negara kepada Negara Bagian untuk pembangunan fakultas-fakultas pertanian dan teknik, membantu sekolah dengan program makan siang, menyediakan pendidikan bagi orang-orang Indian, menyediakan dana pendidikan bagi para veteran yang kembali ke kampus untuk menempuh pendidikan lanjutan, menyediakan pinjaman bagi mahasiswa, menyediakan anggaran untuk keperluan penelitian, pertukaran mahasiswa asing dan bantuan berbagai 
kebutuhan mahasiswa lainnya, serta memberikan bantuan tidak langsung (karena menurut ketentuan Undang-Undang Amerika Serikat pemerintah dilarang memberikan bantuan langsung) kepada sekolah-sekolah agama dalam bentuk buku-buku teks dan laboratorium.

Namun semenjak masa Pemerintahan Presiden Ronald Reagen, intervensi Pemerintah Pusat AS terhadap pendidikan mulai dikurangi. Hal ini terungkap dalam kepercayaan Reagen bahwa pemerintah terlalu mencampuri kehidupan masyarakat. Ia ingin mengurangi program-program yang menurutnya tidak dibutuhkan rakyat dengan menghapus "pemborosan, penipuan, dan penyalahgunaan." ${ }^{3}$ Selanjutnya tanggung jawab dan inisiatif kebijakan pendidikan diserahkan kepada Negara Bagian (setingkat Propinsi) dan Pemerintah Daerah/Distrik (setingkat Kabupaten/Kota). Di Amerika Serikat terdapat 50 negara bagian dan 15.358 distrik. Jadi sebanyak itu lembaga yang diberi kewenangan dan otonomi untuk mengelola pendidikan.

\section{Tujuan Pendidikan AS}

Sistem pendidikan di Amerika Serikat (AS) mencerminkan ciri dari sistem pemerintahan di sana yaitu federal dengan desentralisasi melalui pemerintahan negara-negara bagian (states). Penanggung jawab utama sistem pendidikan di sana adalah departemen pendidikan pemerintah federal di Washington D.C, namun kegiatan sehari-hari didelegasikan penuh kepada pemerintah setiap Negara bagian yang kemudian mendelegasikannya lagi kepada Kantor Pendidikan Distrik (Public School District), dan kepada badan-badan penyantun college dan universitas.

Sebagaimana dideskripsikan di atas bahwa karakteristik utama politik sistem pendidikan Amerika Serikat adalah menonjolnya desentralisasi. Pemerintah Pusat sangat memberi otonomi seluas-luasnya kepada Pemerintah di bawahnya, yaitu Negara Bagian dan Pemerintah Daerah (Distrik). Meskipun Amerika Serikat tidak mempunyai sistem pendidikan yang terpusat atau yang bersifat nasional, akan tetapi bukan berarti tidak ada rumusan tentang tujuan pendidikan yang berlaku secara nasional. Tujuan sistem pendidikan Amerika secara umum dirumuskan dalam 5 poin sebagai berikut:

a. Untuk mencapai kesatuan dalam keragaman;

b. Untuk mengembangkan cita-cita dan praktek demokrasi;

${ }^{3}$ Richard Hofstadter, dkk. (2004). Garis Besar Sejarah Amerika Serikat. Deplu AS. Hlm. 417418. 
c. Untuk membantu pengembangan individu;

d. Untuk memperbaiki kondisi social masyarakat; dan

e. Untuk mempercepat kemajuan nasional.

Di luar 5 tujuan tersebut, Amerika Serikat mengembangkan visi dan missi pendidikan gratis bagi anak usia sekolah untuk masa 12 tahun pendidikan awal, dan biaya pendidikan relatif murah untuk tingkat pendidikan tinggi.

\section{Manajemen Pendidikan AS}

Manajemen pendidikan di AS dikembangkan berdasarkan aspirasi dan kebutuhan masyarakat Negara Bagian dan Pemerintah Daerah setempat. Hal ini dilakukan mengingat AS adalah Negara dengan system desentralisasi. Di tingkat nasional (federal/pusat) dibentuk satu departemen, yaitu Departemen Pendidikan Federal. Jadi meski dalam sistem pendidikan di Amerika, sekolah adalah tanggung jawab pemerintah lokal, Deparemen Pendidikan menyediakan kepeminpinan nasional untuk menjawab isu-isu penting dalam pendidikan Amerika. ${ }^{4}$ Departemen ini dipimpin oleh seorang setaraf Sekretaris Kabinet. Tugas departemen ini adalah melaksanakan semua kebijakan pemerintah federal dalam sektor pendidikan di semua tingkatan pemerintahan dan untuk semua jenjang pendidikan. Tetapi, karena sebagian besar kewenangan dan tanggung jawab pendidikan sudah diserahkan kepada Negara Bagian dan Pemerintah Daerah, maka Departemen Pendidikan Federal hanya menjalankan monitoring dan pengawasan saja.

Di tingkat Negara Bagian dibentuk sebuah badan yang diberi nama Board of Education. Badan ini bertugas dan berfungsi membuat kebijakankebijakan serta menentukan anggaran pendidikan untuk masing-masing wilayah (Negara Bagian) nya, khususnya berkenaan dengan Pendidikan Dasar dan Pendidikan Menengah. Selanjutnya, untuk menangani permasalahan yang berkaitan dengan hal-hal yang lebih teknis (yaitu; tentang kurikulum sekolah, penentuan persyaratan sertifikasi, guru-guru, dan pembiayaan sekolah) dibentuk sebuah bagian pendidikan yang disebut sebagai comissioner, sering juga disebut sebagai superintendent Bagian ini dipimpin oleh seorang yang ditunjuk oleh Board of Education atau oleh Gubernur.

\footnotetext{
${ }^{4}$ Richard C. Schroeder. (2000). Garis Besar Pemerintahan Amerika Serikat. Deplu AS.hlm.
} $62-63$. 
Untuk beberapa Negara Bagian, pimpinan Bagian Pendidikan ini dipilih oleh masyarakatada. Sementara itu pada level operasional, pelaksanaan manajemen pendidikan dijalankan oleh unit-unit yang lebih rendah, bahkan banyak secara langsung dilaksanakan oleh masing-masing sekolah yang bersangkutan. Para pimpinan atau Kepala Sekolah pada prinsipnya memiliki kebebasan dan otonomi yang luas untuk menjalankan manajemen operasional pendidikan. Khusus untuk menangani kebijakan Pendidikan Tinggi, manajemen pendidikan Amerika Serikat yang dikembangkan oleh Negara-Negara Bagian memisahkan antara Badan yang memberi izin pendirian Perguruan Tinggi (Negeri dan Swasta) dengan Badan yang merumuskan kebijakan akademik serta keuangan. Badan yang menangani kebijakan akademik dan keuangan untuk pendidikan Tinggi adalah board of trustees. Untuk Perguruan Tinggi Negeri anggota badan tersebut ditunujuk oleh Gubernur Negara Bagian. Ada juga yang dipilih dari dan oleh kelompok yang akan diwakili. Sedangkan untuk Perguruan Tinggi Swasta anggota badan tersebut dipilih dari perguruan tinggi masing-masing.

\section{E. Pendanaan Pendidikan AS}

Sumber pendanaan pendidikan di Amerika, khususnya pendidikan dasar dan menengah, yang lebih dikenal dengan public schools, berasal dari Anggaran Pemerintah Pusat (Federal), Anggaran Pemerintah Negara Bagian dan Anggaran Pemerintah Daerah.

\section{F. Isu-isu Pendidikan AS}

Pada dekade 1990-an, Departemen Pendidikan memfokuskan pada isuisu berikut: meningkatkan standar seluruh siswa, memajukan pengajaran, melibatkan orangtua dan keluarga dalam pendidikan anak, penciptaan sekolah yang aman, disiplin dan bebas narkoba, mempererat hubungan antara sekolah dan dunia kerja, meningkatkan akses bantuan financial untuk para siswa agar dapat kuliah dan menerima pelatihan, serta membantu seluruh siswa agar melek teknologi. ${ }^{5}$

Menurut hasil studi perbandingan yang dilakukan oleh Agustiar Syah Nur (2001), seperti dikutip oleh Ulul Albab; ada beberapa isu dan masalah pendidikan yang dialami pemerintah dan masyarakat Amerika Serikat, antara lain: 
a. Banyaknya anak usia sekolah yang tidak diasuh langsung oleh orang tua mereka, karena adanya dinamika perubahan social masyarakat AS yang umumnya baik sang ibu atau sang ayah memiliki kesibukan yang sangat tinggi di luar rumah. Hal ini akan

a. menjadi permasalahan yang serius bagi perkembangan social anak dilihat dari aspek psikis dan emosional.

b. Tingginya tingkat perceraian, yang mengakibatkan banyaknya anak-anak usia sekolah yang hanya diasuh oleh sang ibu sebagai single-parent dalam rumah tangga. Tidak sedikit janda cerei di AS yang terpaksa harus berporfesi rendahan dan kasar. Hal ini jugamempengaruhi perkembangan social anak-anak mereka.

c. Tingginya tingkat imigrasi yang umumnya berasal dari kalangan tidak mampu dan tidak terdidik, yang karenanya banyak diantara mereka yang tidak memperoleh pekerjaan yang layak. Hal ini menyebabkan masalah pendidikan anak-anak dari keluarga imigran tidak dapat teratasi. Ditambah lagi faktor bahasa dari kalangan imigran yang menyulitkan bagi anak-anak imigran itu sendiri jika mereka mendapat akses pendidikan.

d. Dari berbagai monitoring dan evaluasi pendidikan yang dilakukan oleh berbagai badan resmi AS sendiri, ternyata kualitas pendidikan dan lulusan sekolah di AS masih kalah dibandingkan dengan negara-negara lain dalam standar internasional. Banyak anak-anak yang drop-outs dan tingginya kekerasan oleh anak-anak.

\section{G. Reformasi Pendidikan AS}

Karena adanya berbagai permasalahan tersebut, pemerintah AS sejak tahun 1990 mencanangkan reformasi pendidikan. Nampaknya George Bush masih melanjutkan kebijakan Reagen bahwa terdapat industri swasta serta pemerintah local dan Negara bagian turut menanggung biaya kebijakan pemerintah. Pada tahun tersebut Presiden AS George H. B. Bush beserta seluruh Gubernur Negara Bagian (saat itu Bill Clinton termasuk menjadi salah satu Gubernur Negara Bagian) menyetujui reformasi pendidikan dengan mencanangkan 6 tujuan nasional pendidikan AS yang baru. Yaitu:

a. Pada tahun 2000, seluruh anak di AS di waktu mulai masuk sekolah dasar sudah siap untuk belajar.

b. Pada tahun 2000, tamatan sekolah menengah naik sekurang-kurangnya $90 \%$. 
c. Pada tahun 2000 , murid-murid di AS yang menyelesaikan pendidikannya pada "grade 4, 8 dan 12" mampu menunjukkan kemampuannya dalam mata pelajaran yang menantang, yaitu bahasa inggris, matematika, sains, sejarah, dan geografi. Setiap sekolah di AS harus mampu menunjukkan bahwa anakanak dapat menggunakan pikirannya dengan baik, sehingga mereka siap menjadi warga negara yang baik, siap untuk memasuki pendidikan yang lebih tinggi, serta siap pula untuk pekerjaan yang produktif dalam perekonomian modern.

d. Pada tahun 2000, siswa-siswa AS adalah yang terbaik di dunia dalam bidang sains dan matematika.

e. Pada tahun 2000, setiap orang dewasa AS dapat membaca dan menulis, memiliki ilmu pengetahuan dan keterampilan yang diperlukan untuk bersaing dalam ekonomi global, serta dapat melaksanakan hak dan tanggung jawabnya sebagai warga negara.

f. Pada tahun 2000, setiap sekolah di AS harus bebas dari obat-obat terlarang dan kekerasan, serta dapat menciptakan suasana lingkungan yang mantap dan aman sehingga kondusif untuk belajar.

Pokok-pokok reformasi tersebut dimaksudkan sebagai pegangan dalam membuat kebijakan-kebijakan pendidikan yang sudah harus segera diimplementasikan dan hasilnya sudah harus kelihatan pada tahun 2000. Dan memang itulah yang terjadi di AS. Pokok-pokok reformasi pendidikan itu akhirnya ditindak lanjuti dengan berbagai kreasi kebijakan pendidikan di tingkat negara bagian dan pemerintah derah. Gerakan reformasi pendidikan di kalangan Gubernur itu dipelopori oleh Gubernur Bill Clinton dan Lamar Alexander di masing-masing negara bagiannya. Gebrakan yang dilakukan adalah:

a. Meningkatkan persyaratan untuk menamatkan suatu jenjang pendidikan

b. Melaksanakan test standar untuk mengukur keberhasilan siswa

c. Menjalankan sistem penilaian yang ketat terhadap guru sejalan dengan pembenahan jenjang karir bagi guru-guru

d. Memperbesar tambahan dana dari negara bagian bagi sekolah sekolah. Tambahan dana baru ini pada umumnya dipakai untuk meningkatkan gaji guru yang kala itu masih berada pada taraf sangat rendah.

Akhirnya AS benar-benar memperoleh kemajuan di bidang pendidikan, sehingga ketika Bill Clinton menjadi Presiden AS, keberhasilan AS dalam mengembangkan kebijakan pendidikan mendapat perhatian khusus. 


\section{H. Penutup}

Dari deskripsi kebijakan pedidikan yang diambil pemerintah Amerika Serikat, tentunya banyak hal yang mungkin saja dapat diambil sisi-sisi yang sekiranya baik untuk dijadikan referensi dalam rangka meningkatkan kualitas sistem pendidikan di negara kita. Ternyata sudah menjadi kultur budaya yang sangat mengakar dalam sejarah AS bahwa pendidikan menjadi tugas bagi keluarga dan masyarakat. oleh karena itu masyarakat tidak mau kalau pendidikan diatur oleh pemerintah pusat, bahkan oleh pemerintah negara bagian, bahkan oleh pemerintah lokal sekalipun. Masyarakat merasa memiliki hak yang sangat kuat untuk menentukan sistem pendidikan seperti apa yang paling tepat untuk masyarakat mereka. Mereka menganggap tantangan yang dihadapi oleh setiap komunitas tidaklah sama, jadi sistem pendidikan juga tidak boleh atau tidak perlu disamakan antara satu kota dengan kota lain, antara satu state dengan state lain. Kita melihat masih terlalu banyak problema dan ketidakpuasan diseputar persoalan pendidikan ini, tetapi sebagai bangsa yang besar dan sudah tua mereka sangat berpengalaman dalam memberikan respon yang cepat dan tepat dalam mengatasi permasalahan-permasalahan yang terjadi. Karakter ini sudah menjadi budaya bangsa Amerika yang perlu kita pelajari untuk kita ambil manfaatnya.

\section{DAFTAR PUSTAKA}

Richard Hofstadter, dkk. 2004. Garis Besar Sejarah Amerika Serikat. Deplu AS.

Richard C. Schroeder. 2000. Garis Besar Pemerintahan Amerika Serikat. Deplu AS.

Richard N. Current. 1965. American History: A Survey. New York: Alfred A. Knopft.

Tadashi Fukutake. 1988. Masyarakat Jepang Dewasa Ini. Jakarta: PT. Gramedia Pustaka

Sumber dari Internet: 
http://hendronurprasetyo.blogspot.com/2007/07/sistem-pendidikan-di-amerikaserikat.html

http://www.unitomo.ac.id/artikel/ululalbab/edu policy/babempat.pdf

\section{Tentang Penulis}

Taat Wulandari, S. Pd. Merupakan dosen pada Jurusan Pendidikan Sejarah, FISE, UNY. Saat ini sedang menyelesaikan pendidikan S2 pada Program Studi PIPS Universitas Negeri Yogyakarta. Saat ini mengampu mata kuliah: Sejarah Amerika, Sejarah Pemikiran, dan Pendidikan IPS. 